\title{
Bisphosphonates in the treatment of metabolic bone diseases
}

\author{
Atualização sobre bisfosfonatos nas doenças osteometabólicas
}

Henrique Pierotti Arantes', André Gonçalves da Silva', Marise Lazaretti-Castro'

1 Departamento de Endocrinologia,

\section{SUMMARY}

Unidade de Metabolismo

Osteoporosis is a disease characterized by low bone mass associated with the deterioration of Ósseo e Mineral, Universidade Federal de São Paulo (Unifesp), São Paulo, SP, Brasil microarchitecture, due to an imbalance either in high bone resorption or low bone formation or in both, leading to a high risk of fractures. Bisphosphonates are medications which reduce the ability of osteoclasts to induce bone resorption and consequently improve the balance between resorption and formation. There are bisphosphonates approved for the prevention and treatment of osteoporosis. Administration can be oral (daily, weekly or monthly) or intravenous (quarterly or yearly). These medications are well tolerated and with the correct instructions of administration have a good safety profile. Serious side effects, such as, osteonecrosis of jaw is very rare. Bisphosphonates are the most prescribed medication for the treatment of osteoporosis. Arq Bras Endocrinol Metab. 2010;54(2):206-12

Keywords

Bisphosphonates; mechanism of action; osteoporosis treatment; side effects

\section{SUMÁRIO}

Correspondence to: Marise Lazaretti-Castro Rua Borges Lagoa, 800 04038-001 - São Paulo, SP, Brasil lazaretti.castro@unifesp.br

Received on Jan/9/2009 Accepted on Feb/9/2010
Osteoporose é uma doença caracterizada por baixa massa óssea associada à deterioração da microarquitetura devido ao desbalanço pela alta reabsorção, baixa formação ou ambas, levando a um alto risco de fraturas. Bisfosfonatos são medicamentos que reduzem a capacidade de os osteoclastos induzirem a reabsorção óssea e, consequentemente, melhorar o balanço entre reabsorção e formação. Há bisfosfonatos aprovados para prevenção e tratamento da osteoporose. A administração pode ser via oral (diária, semanal ou mensal) ou intravenosa (trimestral ou anual). Essas medicações são bem toleradas e, seguindo as recomendações adequadas, apresentam alto grau de perfil de segurança. Efeitos colaterais sérios, como osteonecrose de mandíbula, são raros. Bisfosfonatos são as medicações mais prescritas para o tratamento da osteoporose. Arq Bras Endocrinol Metab. 2010;54(2):206-12

Descritores

Bisfosfonatos; mecanismo de ação; tratamento da osteoporose; efeitos colaterais

\section{INTRODUCTION}

$\mathrm{O}$ steoporosis is defined as a metabolic bone disease characterized by low bone mass associated with the deterioration of bone microarchitecture, leading to increased risk of fragility and consequently fractures (1).

The uncoupling of bone remodeling is involved in the pathophysiology of osteoporosis, with increased resorption and reduced bone formation. Bone remodeling is defined as a coupled process between bone resorption (performed by osteoclasts derived from hematopoietic cells in a process lasting 3 weeks on average) and bone formation (promoted by osteoblasts which are cells de- rived from mesenchymal precursors and this process takes 3 to 4 months to be completed) (2). In this regard, drugs that decrease bone resorption, the antiresorptives, are a form of treatment for osteoporosis among which the bisphosphonates are the most widely used.

\section{MECHANISM OF ACTION}

Bisphosphonates are synthetic pyrophosphate analogues with two phosphate groups that bind hydroxyapatite with high affinity. The central carbon binds the Rl side chain, often a hydroxyl group, which binds calcium and allows for more stable interaction with 
the bone matrix (3). The R2 side chain gives each bisphosphonate its characteristic properties and potency. Bisphosphonates can be classified based on the presence or absence of a nitrogen atom in the R2 side chain. Nitrogen-containing bisphosphonates (alendronate, risedronate, ibandronate, and zoledronic acid) are more potent inhibitors of osteoclast action. These side-chain differences explain, in part, differences between the aminobisphosphonates: their affinity and adherence to the hydroxyapatite surface; their diffusion into bone; their displacement from this adherence and physiochemical binding when bisphosphonates are discontinued (offset); and the differences in their ability to inhibit the mevalonic acid pathway enzyme, farnesyl pyrophosphate synthetase (FPPS) (4). Non-amino bisphosphonates disrupt the ATP metabolic pathway in osteoclasts that leads to osteoclast apoptosis, while the amino bisphosphonates impair FPPS. This inhibitory effect on FPPS leads to reduced osteoclast capacity to prenylate specific intracellular proteins necessary for normal osteoclastic cell function (5). The end result is a reduced ability of osteoclasts to induce bone resorption and to induce programmed cell death (apoptosis) of osteoclasts (Figure 1).

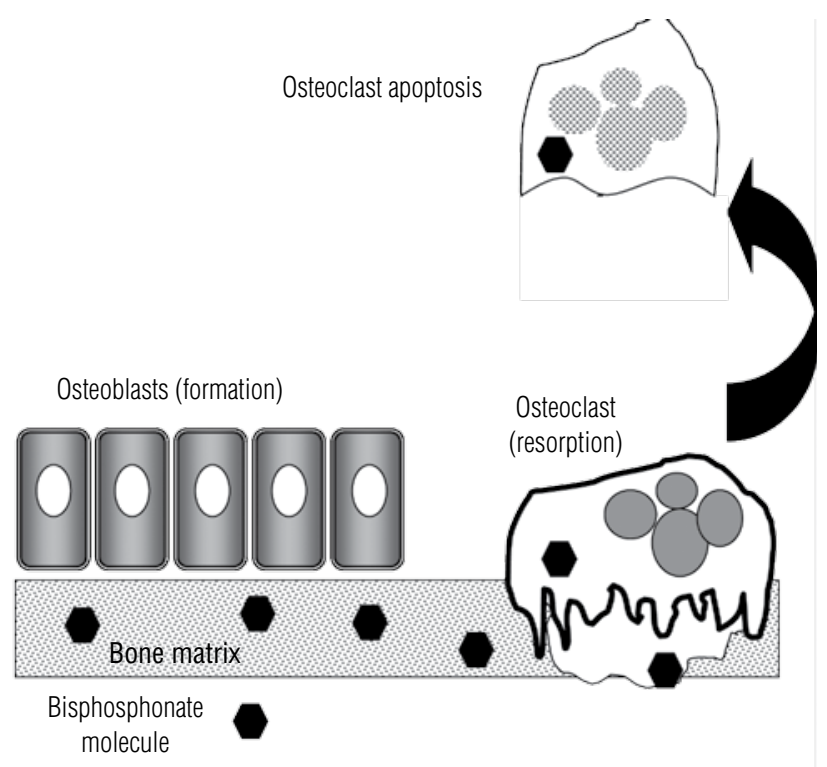

Figure 1. Bisphosphonates are rapidly incorporated to mineralized bone matrix. During bone resorption they are captured by osteoclasts. When inside these cells, bisphosphonates induce an inhibition of their function by disrupting the ATP metabolic pathway and by impairing the enzyme FPPS (for amino-bisphosphonates), disorganizing their cytoskeletal. These effects decrease osteoclast activity and induce their apoptosis, interrupting local bone resorption.
Bisphosphonates are not metabolized by pyrophosphatases. They have very high affinity for bone surface. What does not bind to bone is excreted in the urine unchanged $(6,7)$. Bisphosphonates are poorly absorbed by the gut, with less than $1 \%$ bioavailability after oral administration (8). This poor absorption is related to the heavy negative charge of the bisphosphonate molecule, which makes transport across lipophilic cell membranes difficult. What is absorbed usually has a powerful effect on bone turnover. Up to $50 \%$ of the absorbed or intravenously administered dose is quickly taken up by the skeleton (9).

Bisphosphonates have an extremely high affinity for bone, and bone is almost the exclusive tissue that takes up bisphosphonates. This selective tissue uptake is due to two major and distinctly different reasons: 1) Bisphosphonates bind to the denuded bone resorptive cavity as a consequence of osteoclastic removal of bone tissue during remodeling (physiochemical effect); 2) Only phagocytic cells (osteoclasts and macrophages) can take up bisphosphonates (cellular effect).

Recent data suggest that bisphosphonates increase serum osteoprotogerin (OPG) levels (an osteoblastderived protein) and that these increases are correlated with increases in bone mineral density (BMD) (10).

Fractures are the most important clinical manifestation of osteoporosis and can cause substantial morbidity (11) and mortality (12). Because of this, any available anti-osteoporotic drug needs to clearly demonstrate its efficacy in reducing fracture risk. Treatment with antiosteoporotic drugs such as bisphosphonates not only increases BMD but also significantly reduces vertebral fracture relative risk by as much as $40 \%-50 \%(13,14)$.

There is evolving evidence that patients may prefer a weekly or monthly bisphosphonate formulation over the fracture-proven daily dosing formulation (15). Better compliance and adherence to therapy may result in better outcomes (e.g., fracture risk reduction) for some patients than for those who are less compliant with their medication (16). In the real world of clinical practice having choices is good.

Specific bisphosphonate molecules approved for the treatment of osteoporosis are:

1) Alendronate $(10 \mathrm{mg} /$ day and $70 \mathrm{mg}$ /week): alendronate is the most used amino-bisphosphonate and the first to be approved by the FDA for treatment of postmenopausal osteoporosis. An observational trial with alendronate followed patients for up to 10 years. It reduces the incidence of vertebral fracture, non- 
vertebral and proximal femur. In the alendronate data set, there have been two extension studies. The first, an extension of the initial phase III study (17), with 10-year's data published (18). The second, an extension study of the alendronate-FDA registration study, the fracture intervention trial (FIT), with the 10-year data given the name of FLEX (19).

2) Risedronate $(5 \mathrm{mg} /$ day and $35 \mathrm{mg} /$ week, orally): in the risedronate clinical trial data set, there are 5 -year data in which a subset from the original multinational group was maintained on placebo and another was maintained on risedronate (20). New incident vertebral fractures continued to be reduced during the 4 th and 5 th year in the treated group, which provides evidence of long-term fracture benefit over 5 years of treatment. More recently, Delmas and cols. (21) compared risedronate $150 \mathrm{mg} /$ month with risedronate $5 \mathrm{mg} /$ day. Based on comparisons with the historical control group, monthly risedronate was similar to the $5 \mathrm{mg} /$ day dose in reducing the risk of new vertebral fractures during the first year of treatment.

3) Ibandronate $(2.5 \mathrm{mg} /$ day orally, $150 \mathrm{mg} /$ month orally, every 3 months intravenously): ibandronate has been shown to increase BMD (22). In this study (MOBILE), women receiving $150 \mathrm{mg} /$ month oral ibandronate exhibited significantly larger increases in lumbar spine (LS) BMD compared with women receiving ibandronate $2.5 \mathrm{mg}$ /day orally $(6.6 \%$ versus $5.0 \%$, $\mathrm{P}<0.001)$. Another study (BONE) demonstrated that daily ibandronate therapy $(2.5 \mathrm{mg}$ orally $)$ reduced vertebral fracture risk in postmenopausal women (23). Additionally, a post-hoc analysis found that ibandronate decreased the risk of non-vertebral fracture in a highrisk subgroup of patients with femoral neck T-score $\leq 3.0$ (24). Further trials revealed that ibandronate 150 $\mathrm{mg} /$ month orally and ibandronate $3 \mathrm{mg}$ quarterly intravenously (IV) resulted in greater increases in BMD compared with the daily oral regimen (22). A post-hoc analysis from DIVA evaluated the efficacy of ibandronate intra venous on non-vertebral fracture reduction. The relative risk reduction was of $43 \%$ versus the oral formulation (25). These monthly and IV regimens are the currently FDA-approved doses in the USA and both of them are already available in Brazil too.

4) Zoledronic acid $(5 \mathrm{mg} /$ year intravenous infusion): HORIZON Trial reported that a yearly zoledronic acid infusion $(5 \mathrm{mg}$ /year) significantly reduced the risk of vertebral fractures, hip fractures, all non-vertebral fractures and clinical vertebral fractures compared with placebo in postmenopausal women with osteoporosis (26). The HORIZON recurrent fracture trial which evaluated clinical fracture incidence in a group of men and women who received zoledronic acid infusion within 90 days after surgical repair of a low-trauma hip fracture, reported significant reductions in overall clinical fractures and in clinical non-vertebral fractures but not in new hip fractures. A mortality relative risk reduction of $28 \%$ was observed in the treatment group (27).

5) Pamidronate (60 mg IV every 3 months): Pamidronate has not been approved by the FDA for treatment of osteoporosis, but it significantly increases bone mass. In a small study with 61 patients, mean follow-up duration of 4.3 years, pamidronate compared with oral bisphosphonate (alendronate $70 \mathrm{mg} /$ week or risedronate $35 \mathrm{mg}$ /week) showed to be a good option for patients who do not tolerate oral bisphosphonates (28) and who do not have access to zoledronic acid due to its high cost. There are no data about fracture protection with this regimen. There is a summary of bisphosphonates available in table 1 .

Table 1. Summary of the effects of different bisphosphonates on fracture risk reduction, when given with calcium plus vitamin $\mathrm{D}$ for postmenopausal women with osteoporosis

\begin{tabular}{lccc}
\hline & $\begin{array}{c}\text { Vertebral } \\
\text { fracture }\end{array}$ & $\begin{array}{c}\text { Non-vertebral } \\
\text { fracture }\end{array}$ & $\begin{array}{c}\text { Hip } \\
\text { fracture }\end{array}$ \\
\hline Alendronate & $\mathrm{A}$ & $\mathrm{A}$ & $\mathrm{A}$ \\
Ibandronate & $\mathrm{A}$ & $\mathrm{A}$ & $\mathrm{NAE}$ \\
Risedronate & $\mathrm{A}$ & $\mathrm{A}$ & $\mathrm{A}$ \\
Zoledronate & $\mathrm{A}$ & $\mathrm{A}$ & $\mathrm{A}$ \\
Pamidronate & $\mathrm{NAE}$ & $\mathrm{NAE}$ & $\mathrm{NAE}$ \\
\hline
\end{tabular}

A: Approved. NAE: not adequately evaluated.

Adapted from reference 29.

\section{BISPHOSPHONATES - SIDE EFFECTS}

Although bisphosphonates are usually well-tolerated when administered appropriately, several side effects are described with variable morbidity. We review here the most frequent safety concerns related to bisphosphonate therapy.

Gastrointestinal (GI) symptoms are the most frequent side effects attributed to bisphosphonate use. They occur in about $20 \%-30 \%$ of the patients, usually within the first weeks of therapy (30). Experimental studies have previously demonstrated that these drugs are able to promote upper gastrointestinal injury, especially in the context of preexisting esophageal irritation, 
repeated daily exposure, and dyspepsia (31). Bisphosphonates are mostly related to esophageal irritation and ulceration with rarer reports of esophageal perforation or upper gastrointestinal bleeding. Patients complain of heartburn, nausea, and upper abdominal or chest pain (32). Although frequently related to bisphosphonate use, in prospective, randomized, placebo-controlled clinical trials with oral bisphosphonates, there were no significant differences in GI side effects between patients treated with oral bisphosphonates or placebo. Most patients reporting GI intolerance to bisphosphonates are able to continue on the same drug (33); however, Hamilton and cols. (32) demonstrated that $76 \%$ of the patients who discontinued the use of risedronate did so because of gastrointestinal side effects (32). No differences in the incidence of gastrointestinal side effects between daily and weekly or monthly dosing groups in clinical trials were observed (34). This observation may be possibly attributed, at least in part, to improper administration, reporting bias of side effects, or background incidence of GI disorders.

Regardless of the reason for the GI events some patients with GI symptoms may become ineligible to continue oral bisphosphonates therapy and must therefore be considered candidates for other formulations, or even other drugs for osteoporosis. As intravenous (IV) bisphosphonates do not accumulate in the GI tract they can be offered as an alternative for patients with intolerable GI side effects with oral drugs.

By inhibiting osteoclast action on bone turnover bisphosphonates can induce modest, transient, decreases in serum calcium levels, with consequent PTH elevation. In calcium- and vitamin D-replete patients such variations are not associated to symptoms. In patients with hypoparathyroid or in vitamin D-deficient patients, however, symptomatic hypocalcemia may be observed, especially with intravenous, highly-potent bisphosphonates (24). Before treatment with a bisphosphonate, particularly with an intravenous agent, it is prudent to measure serum calcium and vitamin D levels appropriately correcting eventual deficiencies before starting antiresorptive treatment.

Transient flu-like symptoms (acute-phase reaction) sometimes occur during IV bisphosphonate therapy and rarely after oral therapy (33). Acute-phase reaction (APR) is characterized by low-grade fever, myalgia, headache, arthralgias, bone pain, and nausea. It more often occurs in patients not previously exposed to bisphosphonates; recurrence of symptoms during subsequent infusions is unlikely. APR seems to be related to rapid and transient release of proinflammatory cytokines from circulating T-cells (34).

Non-healing lesions of the jaw usually following invasive dental procedures (named osteonecrosis of the jaws - ONJ) have been reported in patients in use of bisphosphonates. Most of those patients (95\%) were receiving high-doses of intravenous bisphosphonates (zoledronic acid or pamidronate) for cancer-related bone disease. Only a small number of patients were receiving treatment for Paget's disease or osteoporosis. Additional risk factors appear to be history of local trauma, dental procedures, or dental infection. The impact of other factors such as smoking and underlying systemic conditions like diabetes mellitus, remains to be determined (35). The pathogenesis is still unknown. Although hypothesized as a possible etiology to the problem stronger reduced bone turnover could not be demonstrated in these patients as a risk factor (30).

For patients in use of bisphosphonate therapy (especially IV bisphosphonates) management is targeted to minimize risk by eliminating active sites of infection (minimizing the need for future dentoalveolar procedures). Whenever necessary, it is prudent to consider conservative alternatives to surgical procedures, with local and systemic antibiotics and minimal bone manipulation. In case of diagnosed ONJ the best measure is to discontinue bisphosphonate therapy, if possible, until osteonecrosis heals (35).

Bisphosphonates generally have been shown to have a benign cardiovascular safety profile. Data from the HORIZON-Pivotal Fracture Trial, however, suggested an increased risk of atrial fibrillation (AF) with use of zoledronic acid (24). This study was a double-blind, placebo-controlled trial in women with postmenopausal osteoporosis randomized to receive IV zoledronic acid ( $5 \mathrm{mg}$ ) or placebo at baseline, at 12 months, and 24 months. A significant reduction in new vertebral and hip fractures was demonstrated. Additional analysis of cardiovascular adverse events during the study, however, showed an increased incidence of AF with zoledronic acid versus placebo ( $1.3 \%$ vs. $0.4 \% ; \mathrm{P}<0.001)$. The significance of those findings must subsequently be confirmed, since the trial was not designed to examine the occurrence of arrhythmias. In the HORIZON Recurrent Fracture Trial, a randomized, double-blind, placebo-controlled trial, 1,065 patients with recent low-trauma hip fracture received annual infusions of zoledronic acid $5 \mathrm{mg}$ and 1,062 received placebo. The median follow-up was 1.9 year and the incidence of new clinical fractures was significantly reduced in the 
group receiving the drug. Careful evaluation of atrial fibrillation showed no differences between the 2 treatment groups in the study (26). Thus, even in a higher risk population such as this one, no arrhythmogenic effect of zoledronic acid has been identified.

Other effects are related to bisphosphonate use. Inflammation of ocular structures, allergic manifestations, and abnormal tests of liver function have been reported. These effects are generally mild and self-limited (30). For some intravenously administered bisphosphonates renal toxicity has been described (36), suggesting the need for renal function testing before and during treatment, dose reductions for mild-to-moderate renal impairment, and caution for patients with severe renal dysfunction.

\section{BISPHOSPHONATE THERAPY AND OTHER SITUATIONS OF BONE LOSS}

Glucocorticoids (GC), when continuously used, are associated with significant side effects, such as bone loss and increased fracture risk, clinically evident within 3 months of starting GC (37). The pathophysiology of glucocorticoid-induced bone loss and fracture is multifactorial; an important related mechanism is osteoblastic dysfunction (38). Bone resorption seems to be enhanced as GC can dose-dependently reduce osteoprotegerin (OPG) and increase RANKL expression with resulting enhanced osteoclastogenesis. In addition to their antiresorptive effects, bisphosphonates inhibit osteoblast and osteocyte apoptosis (with prolongation of their lifespan) induced by GC (39). In patients in use of GC treatment with alendronate 5 or $10 \mathrm{mg} /$ day preserved bone density reducing the risk of morphometric vertebral fractures (38). Risedronate (40) and zoledronic acid (37) are also indicated prevention and treatment for glucocorticoid-induced osteoporosis.

Bisphosphonate treatment prevents bone loss induced by immunosuppressive therapy following organ transplantation by reducing fracture risk (41). Similarly, bisphosphonate therapy is used to blunt bone loss following endocrine ablative therapy with aromatase inhibitors in women with breast cancer (42) or GnRH therapy for men with prostate cancer (43).

\section{HOW LONG SHOULD WE CONTINUE BISPHOSPHONATE TREATMENT?}

The half-life of alendronate is similar to that of bone mineral, approximately 10 years (18). Thus, skeletal effects of alendronate and other bisphosphonates may last for long periods after discontinuation of treatment. This has led some to suggest a "drug holiday", which is a temporary discontinuation of the drug during which patients would still be protected from increased bone turnover and fractures (44). Some reports have described rather unusual fractures that have also exhibited problems with healing in cases where the possibility of oversuppression by bisphosphonates seemed to be the cause $(45,46)$. However, these reports were unable to establish a definitive cause-and-effect relation between the fractures and bisphosphonate therapy. Data about the evolution of bone turnover markers right after discontinuation are lacking, which limits the observation about the persistence of the inhibition of bone turnover during the first months after discontinuation of the drug. However, recent studies $(18,19)$ showed that the levels of bone turnover markers increased within a year after discontinuation of therapy, but below the pretreatment values. A recent randomized controlled trial of 1,099 women who received alendronate for a mean of five years found similar risk of fracture for the next five years among patients who were randomized to placebo versus continued treatment (18). Other trials with long-lasting use of alendronate (17) and risedronate (47) have not observed a higher risk of severe adverse effects either. Data from our own experience, following 40 osteoporotic patients who had their bisphosphonate treatment discontinued after 5 years, in comparison to patients still in use of alendronate $10 \mathrm{mg} /$ day, demonstrated no evidence of excessive bone turnover suppression with elevation of bone resorption (CTX) and formation (PINP) markers during the follow-up (48). About $45 \%$ of the patients suffered clinically-evident bone loss after 1 year, with $5.2 \%$ of bone loss in the control group $(\mathrm{p}<0.001)$. These data suggest that a temporary discontinuation of bisphosphonates after 5 years of treatment does not seem necessary, and does not seem to be safe either, especially for patients with high fracture risk.

\section{CONCLUSION}

Bisphosphonates correct the imbalance in bone remodeling that causes bone loss. Their rapid and sustained action on bone turnover is extensively studied, with protection from both spine and hip fractures very well documented. Although some safety issues generate concern these drugs are usually well-tolerated show- 
ing low incidence of severe side effects. Such attributes make bisphosphonates an important treatment option for the prevention and treatment of various forms of bone loss, including osteoporosis.

Disclosure: Henrique Pierotti Arantes and André Gonçalves da Silva have no conflict of interest. Marise Lazaretti-Castro is a consultant for Sanofi-Aventis and Novartis and participates as principal investigator in clinical research trials supported by Merck, Sharp \& Dohme, Eli Lilly and Pfizer.

\section{REFERENCES}

1. Consensus Development ConferenceV, 1993. Diagnosis, prophylaxis, and treatment of osteoporosis. Am J Med. 1994;90:646-50.

2. Seeman $E$, Delmas PD. Bone quality-the material and structural basis of bone strength and fragility. N Engl J Med. 2006;354:2250-61.

3. Russell RG. Bisphosphonates: from bench to bedside. Ann N Y Acad Sci. 2006;1068:367-401.

4. Lin JH. Bisphosphonates: a review of their pharmacological properties. Bone. 1996;18:75-85.

5. Dunford JE, Rohers MJ, Ebetino FH, Phipps RJ, Coxon FP. Inhibition of protein prenylation by bisphosphonates causes sustained activation of Rac, Cdc42, and Rho GTPases. J Bone Miner Res. 2006;21:684-94.

6. Papapoulos SE. Pharmacodynamics of bisphosphonates in man: implications for treatment. In: Bijvoet OLM, Fleisch $\mathrm{H}$, Canfield $\mathrm{RE}$, Russell RGG, eds. Therapy in acute and chronic bone loss. Amsterdam: Elsevier Science; 1995. p. 231-63.

7. Papapoulos SE. Bisphosphonates: pharmacology and use in the treatment of osteoporosis. In: Marcus R, Feldman D, Nelson D, Rosen C, eds. Osteoporosis. Philadelphia, PA: Academic Press; 1996. p. 1209-34.

8. Gertz BJ, Holland SD, KlineWF, Matuszwski BK, Freeman A, Quan H. Studies of the oral bioavailability of alendronate. Clin Pharmacol Ther. 1995;58:288-98.

9. Reszka AA, Rodan GA. Mechanism of action of bisphosphonates. Curr Osteoporos Rep. 2003;1:45-52.

10. Dobnig H, Hofbauer LC, Viereck V, Obermayer-Pietsch B, Fahrleitner-Pammer A. Changes in the RANK ligand/osteoprotegerin system are correlated to changes in bone mineral density in bisphosphonate-treated osteoporotic patients. Osteoporos Int. 2006;17(5):693-703.

11. Cranney A, Tugwell P, Adachi J, Weaver B, Zytaruk N, Papaioannou $A$, et al. Meta-analyses of therapies for postmenopausal osteoporosis. III. Meta-analysis of risedronate for the treatment of postmenopausal osteoporosis. Endocr Rev. 2002;23:517-23.

12. Cranney A, Wells G, Willan A, Griffith L, Zytaruk N, Robinson V, et al. Meta-analyses of therapies for postmenopausal osteoporosis. II. Meta-analysis of alendronate for the treatment of postmenopausal women. Endocr Rev. 2002;23:508-16.

13. Lips P, van Schoor NM. Quality of life in patients with osteoporosis. Osteoporos Int. 2005;16:447-55.

14. Center JR, Nguyen TV, Schneider D, Sambrook PN, Eisman JA. Mortality after all major types of osteoporotic fracture in men and women: an observational study. Lancet. 1999;353:878-82.

15. Cramer JA, Amoktar MM, Hebborn A, Altman R. Compliance and persistence with bisphosphonate dosing regimens among women with postmenopausal osteoporosis. Curr Med Res Opin. 2005;21(9):1453-60.

16. Caro JJ, Isaac KJ, Huybrechts KF, Raggio G, Naujoks C. The impact of compliance with osteoporosis therapy on fracture rates in actual practice. Osteoporos Int. 2004;15:1003-8.
17. Liberman UA, Weiss SR, Broll J, Minne HW, Quan $\mathrm{H}$, Bell NH, et al. Effect of oral alendronate on bone mineral density and the incidence of fractures in postmenopausal osteoporosis. N Engl J Med. 1995;333:1437-43.

18. Bone HG, Hosking D, Devogelaer JP, Tucci JR, Emkey RD, Tonino $\mathrm{RP}$, et al. Ten years' experience with alendronate for osteoporosis in postmenopausal women. N Engl J Med. 2004;350:1189-99.

19. Black DM, Schwartz AV, Ensrud KE, Cauley JA, Levis S, Quandt $\mathrm{SA}$, et al.; for the FLEX research group. Long-term experiences with fractures with alendronate: The FLEX (fosamax long-term extension). JAMA. 2007;296:2927-38.

20. Sorenson $\mathrm{OH}$, Crawford GM, Mulder H, Hosking DJ, Gennari C, Mellstrom $D$, et al. Long-term efficacy of risedronate: A 5-year placebo-controlled clinical experience. Bone. 2003;32:120-6.

21. Delmas PD, McClung MR, Zanchetta JR, Racewicz A, Roux C, Benhamou $\mathrm{CL}$, et al. Efficacy and safety of risedronate $150 \mathrm{mg}$ once a month in the treatment of postmenopausal osteoporosis. Bone. 2008;42(1):36-42.

22. Reginster JY, Adami S, Lakatos P, Greenwald M, Stepan JJ, Silverman $\mathrm{SL}$, et al. Efficacy and tolerability of once-monthly oral ibandronate in postmenopausal osteoporosis: 2 year results from the MOBILE study. Ann Rheum Dis. 2006;65:654-61.

23. Chesnut $\mathrm{CH}$, Ettinger MP, Miller PD, Baylink DJ, Emkey R, Harris $\mathrm{ST}$, et al. Ibandronate produces significant, similar antifracture efficacy in North American and European women: new clinical findings from BONE. Curr Med Res Opin. 2005;21:391-401.

24. Chesnut $\mathrm{CH}$, Skag A, Christiansen $\mathrm{C}$, Recker R, Stakkestad JA, Hoiseth $A$, et al. Effects of oral ibandronate administered daily or intermittently on fracture risk in postmenopausal osteoporosis. J Bone Miner Res. 2004;19:1241-9.

25. Sambrook P, Cranney A, Adachi JD. Risk reduction of non-vertebral fractures with intravenous ibandronate: post-hoc analysis from DIVA. Curr Med Res Opin. Epub 2010. Jan 8.

26. Black DM, Delmas PD, Eastell R, Reid IR, Boonen S, Cauley JA, et al. Once-yearly zoledronic acid for treatment of postmenopausal osteoporosis. N Engl J Med. 2007;356:1809-22.

27. Lyles KW, Colon-Emeric CS, Magaziner JS, Adachi JD, Pieper CF, Mautalen $\mathrm{C}$, et al. Zoledronic acid and clinical fractures and mortality after hip fracture. N Engl J Med. 2007;357:1799-809.

28. Eekman DA, Vis M, Bultink IE, Derikx HJ, Dijkmans BA, Lems WF. Treatment with intravenous pamidronate is a good alternative in case of gastrointestinal side effects or contraindications for oral bisphosphonates. BMC Musculoskelet Disord. 2009;10:86.

29. Compston J, Cooper A, Cooper C, Francis R, Kanis JA, Marsh D, et al. Guidelines for the diagnosis and management of osteoporosis in postmenopausal women and men from the age of 50 years in the UK. National Osteoporosis Guideline Group (NOGG). Maturitas. 2009;62(2):105-8. Epub 2009 Jan 8.

30. McClung M. Bisphosphonates. Arq Bras Endocrinol Metabol. 2006;50(4):735-44.

31. Peter CP, Handt LK, Smith SM. Esophageal irritation due to alendronate sodium tablets: possible mechanisms. Dig Dis Sci. 1998;43(9):1998-2002.

32. Hamilton B, McCoy K, Taggart H. Tolerability and compliance with risedronate in clinical practice. Osteoporos Int. 2003;14:259-62.

33. Recker RR, Lewiecki M, Miller PD, Reiffel J. Safety of bisphosphonates in the treatment of osteoporosis. Am J Med. 2009;122:S22-32.

34. Hewitt RE, Lissina A, Green AE, Slay ES, Price DA, Sewell AK. The bisphosphonate acute phase response: rapid and copious production of proinflammatory cytokines by peripheral bloodT cells in response to aminobisphosphonates is inhibited by statins. Clin Exp Immunol. 2005;139:101-11.

35. Woo S, Hellstein JW, Kalmar JR. Systematic review: bisphosphonates and osteonecrosis of the jaws. Ann Intern Med. 2006;144:753-61. 
36. Chang JT, Green L, Beitz J. Renal failure with the use of zoledronic acid. N Engl J Med. 2003;349:1676-9.

37. Reid DM, Devogelaer J, Saag K, Roux C, Lau C, Reginster J, et al. Zoledronic acid and risedronate in the prevention and treatment of glucocorticoid-induced osteoporosis (HORIZON): a multicentre, double-blind, double-dummy, randomised controlled trial. Lancet. 2009;373:1253-63.

38. Van Staa TP. The pathogenesis, epidemiology and management of glucocorticoid-induced osteoporosis. Calcif Tissue Int. 2006;79:129-37.

39. Plotkin LI, Weinstein RS, Parfitt AM, Roberson PK, Manolagas SC, Bellido T. Prevention of osteocyte and osteoblast apoptosis by bisphosphonates and calcitonin. J Clin Invest. 1999;104:1363-74.

40. Devogelaer JP, Goemaere S, Boonen S, Body JJ, Kaufman JM, Reginster JY, et al. Evidence-based guidelines for the prevention and treatment of glucocorticoid-induced osteoporosis: a consensus document of the Belgian Bone Club. Osteoporos Int. 2006;17:8-19.

41. Cohen A, Shane E. Osteoporosis after solid organ and bone marrow transplantation. Osteoporos Int. 2003;14(8):617-30.

42. Fuleihan Gel-H, Salamoun M, Mourad YA, Chehal A, Salem Z, Mahfoud $Z$, et al. Pamidronate in the prevention of chemotherapy-induced bone loss in premenopausal women with breast cancer: a randomized controlled trial. J Clin Endocrinol Metab. 2005;90:3209-14.

43. Smith MR, Eastham J, Gleason D, Shasha D, Tchekmedyian S, Zinner N. Randomized controlled trial of zoledronic acid to prevent bone loss in men receiving androgen deprivation therapy for nonmetastatic prostate cancer. J Urol. 2003;169:2008-12.

44. Curtis JR, Westfall AO, Cheng H, Delzell E, Saag KG. Risk of hip fracture after bisphosphonate discontinuation: implications for a drug holiday. Osteoporos Int. 2008;19(11):1613-20.

45. Odvina CV, Zerwekh JE, Rao DS, Maalouf N, Gottschalk FA, Pak CY. Severely suppressed bone turnover: a potential complication of alendronate therapy. J Clin Endocrinol Metab. 2005;90(3):1294-301.

46. Odvina CV, Levy S, Rao S, Zerwekh JE, Sudhaker Rao D. Unusual mid-shaft fractures during long term bisphosphonate therapy. Clin Endocrinol (Oxf). 2009 Mar 19. [Epub ahead of print]

47. Mellstrom DD, Sörensen $\mathrm{OH}$, Goemaere S, Roux C, JohnsonTD, Chines AA. Seven years of treatment with risedronate in women with postmenopausal osteoporosis. CalcifTissue Int. 2004;75(6):462-8.

48. Silva AG, Lana JL, Kunii IS, Vieira JGH, Lazaretti-Castro M. Bone turnover is not oversuppressed after long term treatment with alendronate (ALN) in patients with postmenopausal osteoporosis: experience from real life (abstract). In 91st Annual Meeting of Endocrine Society Proceedings, 2009 [P1-174]. 